\title{
Masterpiece Theatre and British drama imports on US television: discourses of tension
}

Article

Accepted Version

Knox, S. (2012) Masterpiece Theatre and British drama imports on US television: discourses of tension. Critical Studies in Television, 7 (1). pp. 29-48. ISSN 1749-6020 doi: https://doi.org/10.7227/CST.7.1.5 Available at https://centaur.reading.ac.uk/25047/

It is advisable to refer to the publisher's version if you intend to cite from the work. See Guidance on citing.

To link to this article DOI: http://dx.doi.org/10.7227/CST.7.1.5

Publisher: Manchester University Press

All outputs in CentAUR are protected by Intellectual Property Rights law, including copyright law. Copyright and IPR is retained by the creators or other copyright holders. Terms and conditions for use of this material are defined in the End User Agreement.

www.reading.ac.uk/centaur

\section{CentAUR}


Central Archive at the University of Reading

Reading's research outputs online 


\section{Masterpiece Theatre and British Drama Imports on US Television: Discourses of Tension}

Simone Knox

Having previously written about how US television drama is purchased, broadcast and

received by and on British television, ${ }^{\mathrm{i}}$ I was curious to explore trans-Atlantic televisual flows headed 'the other way.' This essay will therefore think about the presence and significance of British drama imports on US television, using the long-running PBS series Masterpiece Theatre (1971-present) as a case study. With few exceptions, most notably Laurence Jarvik's, Jeffrey S. Miller's and Jeanette Steemers' valuable work, ${ }^{\text {ii }}$ the exporting of British programmes to American television has not received enough sustained scholarly examination. As Steemers points out, following the success of British series in the 1950s and 1960s on US network television, especially ITC shows such as The Adventures of Robin Hood (CBS, 1955-58) or The Prisoner (CBS, 1968), identifiably British programming has enjoyed success with a limited US television audience. ${ }^{\text {iii }}$ In recent years, British export successes have centred on knowledge-based quiz formats (Who Wants to Be a Millionaire?, The Weakest Link), children's shows (Bob the Builder, Teletubbies) and factual event programming (Walking with Dinosaurs) whose British origins are masked respectively through local production, production technique and the choice of subject matter. ${ }^{\text {iv }}$

Nevertheless, identifiably British drama on US television, and Masterpiece Theatre in particular, needs further critical attention.

Although Steemers rightly suggests that 'PBS' low audience share means that British drama is not widely known among mainstream US audiences', ${ }^{\text {v }}$ over the last four decades, Masterpiece Theatre has come to occupy a significant presence in the popular imagination, as affectionate spoofs, including by Sesame Street (PBS, 1969-present) and Buffy the Vampire Slayer (WB, 1997-2001; UPN, 2001-03), attest. Miller makes some pertinent arguments, but his discussion of Masterpiece Theatre appears in one chapter of his monograph, and is focused on the early years of Masterpiece Theatre. Similarly, Jarvik's historical account of PBS and Masterpiece Theatre comes to an end during the 
1980s. Steemers' research considers a more recent time period, but the focus of her work lies elsewhere, concerned with a range of programming, matters of policy and the larger television landscape in the United States (and beyond).

There is space left to - and indeed, in its $40^{\text {th }}$ anniversary year, it is time to explore in detail how Masterpiece Theatre developed and has responded to a changing television landscape. This essay considers how the British programmes on Masterpiece Theatre function in terms of scheduling, promotion, reception, brand identity and quality television debates, and how they may be transformed as part of US television. I pay due attention to the fact that this television environment has undergone significant structural changes in recent decades, including increasing deregulation and market fragmentation; however, my aim is not simply to bring existing scholarship on the series up-to-date, but to challenge some long-standing assumptions about Masterpiece Theatre that persist within a range of discourses. To do so, I draw on archival research of materials held at the Library of American Broadcasting and the National Public Broadcasting Archives (both at the University of Maryland, MD), as well as the Library of Congress (Washington, D.C.), which include transcripts of interviews, in-house memos and publications, the trade press and promotional materials. My discussion is concerned with teasing out a sense of tension, between (apparent) brand stability and (actual) textual diversity and instability, that marks Masterpiece Theatre; tension that has continued across time, and developed with and along the changes of the wider television environment; and tension that existing scholarly research on the PBS series has not quite managed to negotiate.

\section{The Best of the Past?}

\section{Acquisition Policy, the Television Market and Masterpiece Theatre's Brand Identity}

First, a brief overview of Masterpiece Theatre: it is a weekly drama anthology series broadcast on PBS, US television's non-profit public broadcast television service. ${ }^{\mathrm{vi}}$ The Boston PBS station WGBH, which also co-produces a significant amount of the Masterpiece Theatre programming, produces it. Executive-produced first by Christopher Sarson, then Joan Sullivan (aka Joan Wilson), and since 1985 Rebecca Eaton, Masterpiece Theatre began in 1971, following the success of The Forsyte Saga (1969-70) 
on PBS. It is dedicated to showing British television drama, and offerings so far have included Bleak House (two versions, 1985-86 and 2005-06), Cranford (2007-08), David Copperfield (two versions, 1987-88 and 1999-2000), Elizabeth $R$ (1971-72), The Forsyte Saga (the version starring Damian Lewis, 2002-03), I, Claudius (1977-78), Love in a Cold Climate (two versions, 1981-82 and 2001-02), Poldark (1976-77), Pride and Prejudice (two version, 1980-81, starring Elizabeth Garvie, and 2007-08, starring Jennifer Ehle), Upstairs, Downstairs (1973-74) and The Virgin Queen (2005-06). ${ }^{\text {vi }}$ With this programme history, its very name - note the 'theatre (as opposed to the ignoble television) with its British spelling, ${ }^{\text {viii }}$ - and the design of its $\operatorname{logo},{ }^{\mathrm{ix}}$ it is not surprising that Masterpiece Theatre in the United States has become synonymous with quality drama, and a very particular type of quality drama: British costume and literary drama; well acted, well crafted, attentive to detail and measured in its pacing - heritage quality drama replete with the Brideshead/Jewel 'quality components', $\mathrm{x}$ offering 'the best of the past' xi

This brand identity has been received in both positive and negative terms: on the one hand, Masterpiece Theatre has received praise for providing educationally/culturally uplifting programming within the commercial landscape of US television, as befits PBS's remit. On the other hand, it has attracted criticism for an avoidance of "politically sensitive contemporary dramas' xii Miller discusses how this focus on British heritage drama must be understood in the context of the Nixon administration's efforts to neutralise American public broadcasting's critical potential, as well as Masterpiece Theatre's 1971-2004 sponsorship by Mobil Oil (later ExxonMobil), intended to improve the corporation's 'reputation and status among an audience of viewers rich in cultural capital' xiii

This perception of Masterpiece Theatre as staid, backwards-looking and 'safely splendid, ${ }^{\text {xiv }}$ is long-standing and has been reinforced in recent years through the broadcasting of the remakes of The Forsyte Saga and previous hits. Indeed, the very words 'Masterpiece Theatre' have come to circulate in contemporary US culture and debates about television as a pejorative shorthand for Anglophiliac elitism. It is seen as appealing to, as Time Magazine in 2000 scathingly put it, 'buttered-scone Anglophiles [...]: those self-hating televisual Tories who cling to genteel dramas and dotty, dated 
comedies as a Union Jacked bulwark against American TV's tendency to be so crude, so commercial...so American. $^{, \mathrm{xv}}$

However, two issues complicate this heritage shorthand: firstly, it is important to address the generalisation that the costume and literary dramas shown on Masterpiece Theatre are 'safely splendid', or 'simple and safe'. xvi The range and diversity of such texts, which includes the likes of I, Claudius and Bleak House, immediately suggest that not all these programmes inevitably offer nostalgic escapism and fit comfortably into the 'best of the past' heritage shorthand. Additionally, of course, any given costume or literary drama's tone is not inevitably that of nostalgic escapism, requiring careful analysis of the textual choices made to discern the position it offers on its subject matter and/or source material.

Secondly, a closer look at the programme history of Masterpiece Theatre suggests that, from the early years, it showed programmes that do not comfortably fit into this 'best of the past' heritage shorthand: Shoulder to Shoulder (1975-76, a drama about the British suffrage movement broadcast during a period marked by debates about the ratification of the Equal Rights Amendment to the US Constitution), A Very British Coup (1988-89), Talking Heads ('Bed Among the Lentils' 1988-89), Traffik (1989-90), House of Cards (1990-91), Prime Suspect 4 (1995-96), or The Murder of Stephen Lawrence (2001-02). These are outnumbered by the heritage texts, but, possessing 'a wider social and cultural significance which fits public broadcasting's mission', ${ }^{\text {xvii }}$ their presence on Masterpiece Theatre deserves further examination.

It is tempting to understand the presence of such drama as part of a linear historical development, whereby Masterpiece Theatre's acquisition policy changed over time, widening to allow for more textual diversity. To a certain extent, at least, this view is true and useful. Interviewed by Laurence Jarvik, Masterpiece Theatre host Alistair Cooke identified a noticeable change in the buying policy:

I think this has been the bane of the general reputation of Masterpiece Theatre is that it's costume drama. If you look back we haven't done any costume drama for four or five, I don't know how many years. [...] and you'll see little knocks sometime in columns as if we did nothing between Elizabeth and Henry VIII and 
By the Sword Divided. That's the last costume drama we did I think, I mean when you think of A Very British Coup ?viii $^{\text {vii }}$

Similarly, it is true and useful to understand these changes in acquisition policy within the context of both internal and external industrial/institutional developments. Within PBS, Masterpiece Theatre gained competition for British programming in 1980, with the arrival of sister series, Mystery!, showing British crime/detective drama. Cooke explained one of the effects of this on Masterpiece Theatre as follows:

I tell you one thing that makes life a little more difficult in choosing was since the arrival of Mystery. We're not able to have the change of pace and tone that we had when we could have had Thomas Hardy and Balzac and then had Lord Peter Wimsey. You know that's denied us know, of course, because it goes to Mystery. $[\mathrm{sic}]^{\mathrm{xix}}$

While Cooke's reflections here frame Mystery!'s arrival in terms of a narrowing down of available programming for Masterpiece Theatre, I suggest it can also be understood in terms of a broadening out, with the siphoning off of costume/period drama with a crime/detective inflection (and vice versa) encouraging a widening of the range of texts from which to choose.

Changes in Masterpiece Theatre's acquisition policy need to be furthermore understood in relation to external changes in the US television landscape and PBS's position within this. The only regular outlet for British drama when it began in the 1970s, Masterpiece Theatre gained competition for British imports with the spread of cable and the fragmentation of the market in the 1980s. New basic cable channels such as Bravo, USA Network and (particularly) A\&E (which set up an agreement with the BBC), would successfully copy PBS's strategies. They achieved success with imported (and coproduced) British drama, as this was a cost-efficient, risk-minimising way to fill their schedules, aim for market differentiation and appeal to the upscale demographics most likely able to afford cable. Struggling with ongoing financial pressures, as well as political pressures from the Reagan and Bush administrations in the 1980s and early 1990s, PBS was no longer the undisputed home for British drama imports, losing viewers and some of its social impact. 
During the 1990s, responding to the acclaim and success of high-end original drama for pay cable (especially HBO), these basic cable channels moved into domestic production, intent on brand consolidation and younger demographics. As competitors such as A\&E placed less emphasis on the use of British imports, the US television landscape saw further change in the form of the arrival in 1998 of BBC America, a satellite channel owned and operated by BBC Worldwide. Moving into co-productions, BBC America aimed to bring to US television screens British programmes 'closer to the new Beetle than to the Jaguar', ${ }^{\mathrm{xx}}$ including contemporary dramas like Torchwood (200709), with a view to 'raise the profile of the BBC brand with a younger, urban, upscale audience'. xxi

Overall, with such a significant increase in competition, and crucial shifts within this competition, Masterpiece Theatre's efforts to widen its programming palette can be understood as born out of practical necessity: no longer the only US outlet for British (heritage) drama, but, unlike its competitors more specifically committed to British programming and thus dependent on that programming for its very existence, Masterpiece Theatre's market position and bargaining strength became somewhat diminished. Less able to pick and choose freely, it has become increasingly likely to have to commit itself earlier to and pay more for its acquisitions (whilst losing its corporate underwriting in 2004). In terms of branding, movements within its competition to present 'fresher' British fare and the emergence of acclaimed US domestic drama, have tended to make Masterpiece Theatre look more staid, 'starchy' and 'fusty' by comparison. ${ }^{\text {xii }}$ Indeed, with continuing economic and political pressures for public broadcasting, ${ }^{\text {xiii }}$ coupled with the critical acclaim of high-profile and 'edgy' programming on both network and cable television, as the 1990s progressed, US television changed to the point where PBS in general has had to contend with an erosioning of its identity, and Masterpiece Theatre specifically has come to be seen as a lower budget alternative for US audiences, available without having to pay for cable.

However, as true and useful as the views discussed above are, I want to make the argument that the textual diversity on Masterpiece Theatre was not simply precipitated, quite literally brought in, by external forces. This diversity should be understood in terms of a diachronic, ab initio presence of British socio-political drama on Masterpiece 
Theatre that problematises the heritage quality brand identity. There has been an interest in textual diversity and a broadening out of the Masterpiece Theatre programming palette not entirely conditioned by impulses of loss or compulsion. When Rebecca Eaton expressed in 1991 that '[t]elevision has changed. [...] We want to adjust, to move in new directions, ${ }^{\text {xxiv }}$ the 'want' here is not merely a synonym for need, but indicative of a diachronic, $a b$ initio interest in diversity that is, at the very least, consistent with much both external- and internal-facing Masterpiece Theatre self-discourse. For example, an in-house memo from then-executive producer Joan Sullivan revealed a concern for achieving a level of diversity within five years of Masterpiece Theatre's birth:

I guess I would have to say that I'm least excited about this series [The Duchess of Duke Street (1978-79)] of all in next season! Probably because I've had so much UP/DOWN! [...] It's a good respectably strong series but not the freshest format! ${ }^{\mathrm{xxv}}$

Moreover, this interest has not been confined to the level of broadcasting/distribution, but evident at the level of reception. For example, Shoulder to Shoulder 'got a very respectable Nielsen household average of 1.25 million and the highest single-night tunein to date, 1.66 million. ${ }^{\text {xxvi }}$ This compares favourably to the 1.39 million household average for the first season of Upstairs, Downstairs. ${ }^{\text {xvii }}$

However, despite the textual diversity of Masterpiece Theatre's programming, the long-standing perception of its heritage brand identity has persisted. This is both useful, as this assures distinction within an increasingly fragmented market; and problematic, as it suggests that efforts to reposition Masterpiece Theatre - 'to adjust, to move in new directions' - have not successfully registered within press and public discourses. This persistence of the brand identity may be partly an external issue, in that the Masterpiece Theatre shorthand has become too useful and familiar, especially within press discourses. But it may also be linked to an internal tension, in that Masterpiece Theatre has had to negotiate updating its brand image without losing the market visibility and esteem it has built over four decades.

This brings me to the nub of my argument, that there has been a sense of tension within Masterpiece Theatre, between the homogeneous/homogenising heritage brand shorthand and the textual diversity and instability of the programming, which has 
implicated and had a bearing on the programming, as well as the promotional and broadcasting strategies employed. Interestingly, this tension has been paralleled by tension at the level of scholarly discourses about Masterpiece Theatre. Jarvik's writing has acknowledged repeatedly that the acquisition policy evolved towards the inclusion of contemporary social issues, especially with the arrival of Sullivan and Eaton in 1973 and 1985 respectively. ${ }^{\text {xxviii }}$ Nevertheless, Jarvik has made comments such as: 'For almost a quarter-century the series has offered a weekly visit to a peaceful little corner of England'. xxix So here the critical discourse repeats the tensions in the object that it addresses, rather than analysing those tensions. ${ }^{\mathrm{xxx}} \mathrm{I}$ want to tease out some of the tensions that mark Masterpiece Theatre, which I think are strongly implicated in its more recent developments. While Miller has not made similar statements to those offered by Jarvik, his discussion of the early years of Masterpiece Theatre has been focused on texts that fit into the heritage brand, especially Upstairs, Downstairs - of which Shoulder to Shoulder is a near contemporary - so his writing has arguably been marked by the present absence of the tension I am interested in. In some ways, my starting point is Steemers' observation that '[o]riginally based on literary adaptations acquired from the BBC, the strand now draws from a broader range of period and contemporary serials and oneoffs. ${ }^{\mathrm{xxxi}}$ I wish to emphasise, however, that this sense of tension that I perceive has been evident from the early days of Masterpiece Theatre, and that, embedded within a homogenous/homogenising heritage shorthand must lie - inevitably, in many ways more diversity than can be managed by such a shorthand, and that such a shorthand must continually seek to manage it. ${ }^{\text {xxii }}$ Indeed, the shorthand itself is built on tension, seeing as one of its key points of reference, Upstairs, Downstairs, actually elicited initial resistance by WGBH and PBS, because it was not based on a literary source text, not $\mathrm{BBC}$, and indeed from British commercial television. ${ }^{\text {xxiii }}$ I now turn to explore this tension that I argue marks Masterpiece Theatre in relation to matters of scheduling, promotion, broadcasting and reception.

Scones and Herbal Tea: The Scheduling of Masterpiece Theatre 
I flag up the difficulty in assessing how Masterpiece Theatre functions within a larger PBS schedule, as there is no such thing as a single PBS schedule. Although the series has had a consistent timeslot across the PBS stations, each member station determines its own schedule. Therefore, I focus on how Masterpiece Theatre has been used by PBS with regard to the competition on the other channels during the same timeslot. Masterpiece Theatre premiered on a Sunday evening at 9pm, and would occupy this slot until 2001, when PBS moved it to Mondays at 9pm, only to move it back to its old Sunday slot within a year. What were the reasons for this change and subsequent reversal?

Masterpiece Theatre established itself on Sunday nights at a time when the networks would show feature films and the occasional drama series, such as Bonanza (NBC, 1959-1973), and Masterpiece Theatre could peel away audiences looking for (quality) drama. This would change in the mid- to late-1990s, when, beginning with youngest network Fox and The X-Files (1993-2002), the networks and HBO started to take Sunday primetime seriously as a slot for drama, and began to broadcast high-profile series on Sunday nights, such as The X-Files, The Practice (ABC, 1997-2004), Sex and the City (1998-2004) and The Sopranos (1999-2007). Sunday night became an extremely competitive night targeting Masterpiece Theatre-congruent demographics, and PBS decided to move it to Mondays, very likely in the hope that it would do well on the traditional football night on US television. Jacoba Atlas, then-co-chief programming executive at PBS, explained the move back to Sundays as follows: 'What happened was that "Masterpiece" was doing fine on Mondays, but our Sunday night docu series "American Experience" lost some of its audience. ${ }^{\text {xxxiv }}$ However, I suggest that the reversal from Mondays back to Sundays in 2002 needs to be understood in terms of the regular Masterpiece Theatre audience resisting the move to Mondays, as comments on its online forum suggest.

Notwithstanding the continued competitiveness of the Sunday night spot, with high-profile successes continuing into the early-to-mid 2000s (e.g. Boston Legal (ABC, 2004-08), Brothers and Sisters (ABC, 2006-present), Cold Case (CBS, 2003-10) and Desperate Housewives (ABC, 2004-present)), the regular Masterpiece Theatre audience has strongly regarded the Sunday slot as an institution and pleasurable ritual: 
I have been a devoted Masterpiece Theatre viewer for years, and I look forward every week to my 'good drama fix' on Sunday night. It's a perfect way to end the weekend, and Masterpiece Theatre is such an institution in that time slot now that I find it hard to conceive of a Sunday night without it. [...] I hate to think of all that good drama being squeezed into the bustle of an ordinary weeknight $[\ldots] .{ }^{\mathrm{xxv}}$

Watching Masterpiece Theatre on Sunday nights has been understood by these viewers as giving them the chance to concentrate and enjoy the programmes in a more relaxed viewing environment than they would have during the working week, and as enabling families to watch together. There seems to be something quite 'cosy' about watching on a Sunday night that has been perceived as appropriate to the nature of Masterpiece Theatre:

Sunday nights and Masterpiece Theatre have been a treasured institution in our house for over 30 years. If the phone rings, we know it is no one we know because all our close friends know our ritual is to sit down with herbal tea and scones and watch our most favorite television show of all time. ${ }^{\text {xxvi }}$

Clearly, the Masterpiece Theatre audience has regarded Sunday night as a quality-scheduling slot fit for quality programming and a quality audience, and the suggestion by WGBH for those viewers

unable or unwilling to break the Sunday night habit we can suggest the option of videotaping the program on Mondays and watching the following Sunday evening (or at any other time that you prefer). Fortunately, the simple technology of the videotape recorder makes this customizing of your own schedule possible ${ }^{\text {xxxvii }}$

was not favourably received:

$[\ldots]$ it won't be the same to tape and playback later! ${ }^{\mathrm{xxxviii}}$ 
In short, while efforts were made to re-position Masterpiece Theatre through scheduling, the Monday slot was perceived as wrong because of the particular connotations of Masterpiece Theatre, ones which the audience were unwilling to let go. Bearing in mind that subsidy budgets for public broadcasting were further reduced during the 1990s and Mobil stopped its sponsorship in 2004, Masterpiece Theatre has become increasingly dependent on financial support through pledge drives. Therefore, it is interesting to consider that any radical changes to its brand identity of and significant upsets of its core following could have rather detrimental effects for the continued existence of the anthology series.

\section{Tensions within Promotion and Distribution: Textual Instability, Textual Diversity and the Brand}

The presence of Masterpiece Theatre programmes on US television has further been given shape and meaning by its promotional strategies, and especially the meanings mobilised by the now discontinued series of large-scale promotional posters. ${ }^{\text {xxix }}$ Running from 1971 for over two decades, the poster series was begun with the encouragement of Mobil and designed by renowned New York design firm Chermayeff and Geismar. Miller has argued that the narrative image constructed for early successes such as Upstairs, Downstairs combines the dual appeal of "the "upstairs" of "quality" British historical drama and the "downstairs" of soap opera'. ${ }^{x l}$ This linking of quality signifiers (references to the source novel and author, referring to episodes as 'plays') and those of soap (romance, sex, gossip, intrigue) was continued in posters for programmes such as Love in a Cold Climate (1981-82, the poster showing the opulent interior of an Edwardian stately home, with the tagline 'They Were Brought Up To Marry - Not Fall In Love'. The titillation would lessen as the anthology series became more established, but in terms of Masterpiece Theatre's perceived brand identity, it is not surprising that many of the posters, such as those for The Mayor of Casterbridge (1978-79), The Jewel in the Crown (1984-85) and Bleak House (1985-86), would continue to offer signifiers of British quality drama, including British performers, costumes and settings.

However, striking is that several posters did not offer the signifiers of British quality drama in straightforward terms. There is a noticeable strand within the poster 
series that used simple pictorial techniques, such as cut-out shapes, aimed at moving away from the illusion of reality and towards a more abstract style. Examples include the oversimplified, stylised outlines, flat textures and contrasted colours used for the posters for The Barchester Chronicles (1984-85) and Doctor Finlay (1992-93). Drawing on poster art traditions and modernist influences, these styles were playful and drew attention to their own designed-ness. More striking still is another strand, beginning early on in the series' span, which unmistakeably drew on a wide range of art movements, practitioners and painting styles, such as Warholian pop art and Russian revolutionary art (see the poster for Shoulder to Shoulder), Picasso and Modigliani, Cubism and art nouveau, and Surrealism.

These posters were distributed to the national press, PBS stations and New York City bus shelters, which suggests they were aimed at upscale opinion leaders. This underlines Miller's argument, drawing on Pierre Bourdieu's work, that British programmes appeal to elite US demographics, because the marketable signifiers of culturedness reinforce their position as cultural elite. ${ }^{\mathrm{xli}}$ However, reflecting the diversity of texts subsumed within Masterpiece Theatre, I argue that the posters promoted the British texts in such a way that would re-orient meanings away from those of the British heritage paradigm. Drawing on newspaper satirical cartoons in its black-and-white handdrawn design, the poster for A Very British Coup, designed by famous caricaturist Al Hirschfeld, actually underlined the political content of the drama. The poster for Winston Churchill: The Wilderness Years (1982-83), in which Churchill is reduced to a simplified bowler hat and cigar, the smoke of which is turned into an irreverent scribbling out of Churchill's face, highlighted the iconic image of Churchill and at the same time quite literally erased this. Here, the poster drew more attention to the Dada/Magritte-inspired design and sense of playful nonsense than necessarily to the national connotations of the image. Indeed, the use of style and design in the posters to some extent re-oriented meanings away from the Britishness of the content, whereby signifiers of quality were still very much present, but linked with non-British discourses of fine art. ${ }^{\text {xii }}$ As these signifiers overlapped and co-existed with traditional signifiers of Britishness in other posters, the posters evidently bore a sense of tension. 
The promotion energies invested into the series have since moved away from trying to manage that diversity within one promotional process. In 2008, Masterpiece Theatre underwent a major re-branding process and was split into three sub-stands: Masterpiece Classic, Masterpiece Mystery! and Masterpiece Contemporary. With Mystery! now subsumed into the Masterpiece strand, there has been a contracting in, a taking up of the opportunities of integrated brand clustering that is not entirely dissimilar to the dominant practices within commercial television and its vertically integrated consolidation. There has also been a widening out, in that the textual diversity on Masterpiece can now be more easily managed, and that contemporary programming has an unprecedented explicit visibility. The official website now differentiates between these sub-strands through the use of different colour schemes and design and font styles. As Classic is the most dominant, foregrounded within the site, the promotional strategies are still moving both towards and away from the heritage shorthand: tensions persist.

Particular distribution/broadcasting processes have further shaped the text of Masterpiece Theatre. Apart from the already mentioned logo, its opening credits and theme music are worth mentioning: accompanied by its classical theme, the credits for a significant period featured a camera moving through a personal library with oldfashioned armchairs and mahogany tables, showing glimpses of the leather-bound books that had provided material for the series, and other memorabilia that intertextually referenced past successes, such a painting of Henry VIII as a placeholder for The Six Wives of Henry VIII (1971-72). This was thus a self-referential, enclosed space, both inwards- and backwards-oriented.

Partly because the desirable difference of the British texts meant that they did not fit into the grid pattern of the US schedule, Masterpiece Theatre further made use of an on-screen host until 2004, first the British broadcaster and journalist Alistair Cooke (1971-1992), then American Pulitzer Prize-winner Russell Baker (1992-2004), who, as 'high-class filler material,' would give brief introductions and epilogues to the programmes. Cooke described his role as that of a headwaiter in that he is 'there to explain for interested customers what's on the menu, and how the dishes were composed' xliii But of course, his presence did much more than that; Cooke's erudite, 
urbane, literate, articulate and debonair presence reinforced a sense of British culturedness and nostalgia, ${ }^{x l i v}$ as encapsulated by an article in The Observer:

Alistair Cooke [...] remains, for Americans, the Briton par excellence: witty, eloquent - and steeped in nostalgia. As he sat there against his chintz-covered armchair, with an antique table beside him and an old-fashioned lamp lighting his way, Cooke conveyed a Britain that was a million miles removed from the three-day week, strikes, high unemployment and power blackouts. ${ }^{x l v}$

These introductions and epilogues would mobilise certain meanings over others, working towards pushing some potential readings of the series' texts into the background. Cooke and Baker both directed audience attention to what was deemed important, and more importantly, programmes that fell outside of the British heritage paradigm were introduced in a way that acknowledged and highlighted - and thereby reinforced - their difference, as is evident in Baker's introduction for The Murder of Stephen Lawrence (2001-02):

The overriding question is about racism in British society, and whether it's as deeply embedded in Britain as it was in the American South when our own civil rights movement began. This is a highly unusual kind of program for Masterpiece Theatre. $^{\text {xlvi }}$

Evidently, the function of the host was to emphasise both difference and continuity, shifting towards and away from the heritage brand identity; a tension that been reinforced in recent years by the fact that this framing device was dropped in 2004 - partly because it was thought the introductions were not getting the viewers into the dramas as quickly as they should, and changing industrial practices have meant that the increasingly common 'previously on' segment fulfils their function - only to be re-introduced in 2008 as part of the re-branding process. This tension is especially apparent when considering the choice of the first host for Masterpiece Classic, Gillian Anderson, an actor wellknown from contemporary drama series The X-Files and with an important connection to 
British heritage drama because of her role as Lady Dedlock in Bleak House (a literary adaptation noted for its unconventional use of style, no less).

Evidently, the texts on Masterpiece Theatre have been significantly transformed, even physically so: WGBH may re-edit programmes, especially if the start is perceived as too slow, or for matters of taste - a famous example is I, Claudius, which was edited to reduce the sex and violence. This suggests that different versions exist, and indeed, these may even circulate simultaneously: in the wake of the FCC censorship crackdown following Janet Jackson's 2004 Super Bowl halftime show 'wardrobe malfunction,' WGBH made two different versions of Prime Suspect available to PBS stations, one with and one without the (formerly acceptable-in-context) s-word. ${ }^{\text {xlvii }}$ Editorial involvement has become increasingly common in co-productions, including matters of casting, crewing and scripts. However, it is once again important to resist understanding this as part of a linear historiographical development: then-executive producer Joan Sullivan referred in an in-house memo to on-location discussions with the production team of The Duchess of Duke Street, ${ }^{\text {xlviii }}$ which suggests a remarkably close level of involvement as early as the 1970s.

The British texts have been subject to further re-packaging into a different number of episodes (e.g. the 15 half-hour episodes of Bleak House (2005-06) were shown over six weeks). Texts from commercial British television get shown without commercial breaks; BBC, ITV and Channel 4 programming from different years are conflated into 'British drama'; xlix and commercial and BBC texts were linked to the corporate sponsor Mobil. ${ }^{1}$ Programmes from different years have been packaged in new back-to-back combinations and seasons, and, scheduled in one anthology strand in the same weekly time slot, broadcast to a pre-delivered audience. The flexibility and fluidity of textual identity at play here is both evident and particularly significant, as it problematises the heritage shorthand: the homogenised and homogenising Masterpiece Theatre brand identity has always been built on perpetually destabilised and unstable texts. This is possibly the most fundamental tension of all.

Furthermore, these broadcast texts have acquired a different status on Masterpiece Theatre; as Michael Grade put it: 'But what is regarded as classic upmarket upscale programming on PBS is popular programming [in Britain]. ${ }^{\text {li }}$ On Masterpiece Theatre, 
British imports' specificity as British quality drama has defined their meanings - they have become 'Masterpiece Television. 'lii With the heritage brand identity and the particular promotional and distribution/broadcasting processes employed, the textual instability and the potentially problematic actual diversity of the texts, which span a range of genres and styles (consider the differences between Talking Heads, The Jewel in the Crown and Shoulder to Shoulder), have become subsumed under the broader label of British quality television drama. But just as the popularity of 'classic upmarket upscale' programming such as The Forsyte Saga and Upstairs, Downstairs has been much due to 'the tension between the series' "snob" appeal to an educated and established audience and their hailing of the lower-class pleasures of soap opera', liii it is my argument that this conflation and subsumption has not been stable. Inevitably, 'the umbrella provided by the Masterpiece Theatre title will give American audiences a different perception of these programmes' liv But this umbrella will not so much diminish the textual instability and diversity, as actually make this potentially more noticeable, by dint of contrast to the Masterpiece Theatre shorthand. It is in the tension between the homogenised and homogenising brand shorthand and the instability on which it is built, that any (inevitable) variations from the shorthand are likely to draw attention. This hints at matters of reception, to which I turn next.

\section{Discourses of Reception: Distinction and Resistance}

In both US press (newspapers and trade papers) and audience discourses, the perceived Masterpiece Theatre brand shorthand has persisted, and responses to individual nonheritage dramas have continually referred to the inclusion of such programming as an albeit welcome - exception to the rule. It thus raises the question (the convenience of such a yardstick notwithstanding): at what point does the continued existence of exceptions necessitate an amendment of the rule? While both press and audience discourses upheld the shorthand, it has had quite different meanings for each. Invested in the Masterpiece Theatre brand as confirming their own position as cultural elite, its audience has been understandably positive regarding the shorthand, but in a number of interesting ways, including defining Masterpiece Theatre as quality through its proximity 
to literature and the theatre ${ }^{\mathrm{lv}}$ and making explicit comparisons between US and British television drama, judging British to be superior:

We were riveted! When [Talking Heads ('The Hand of God', 2004-05)] was over, it seemed sacrilegious to go back to looking at the usual run, so we turned off the television. [...] In fact, there is nothing on the commercial or cable channels that can compare to PBS programming. ${ }^{\text {lvi }}$

This contrasts with US press commentary on Masterpiece Theatre, which has been more ambivalent, praising individual productions, but showing a suspicion of the remit of Masterpiece Theatre (and PBS) in line with Miller's discussion of the Nixon context, and even questioning the quality status of the anthology series. The following two extracts from the mid-1990s and early 2000s respectively, give a flavour of these persisting misgivings:

Masterpiece Theatre, of course, owes its success to 20th-century American couch potatoes wishing they could be more like the classier British TV couch potatoes. [...] 'MT' [...] has always known how to elevate banal and trashy material into quality costume soap opera. lvii $^{\text {. }}$

But you can't remake Forsyte without inviting the question: Thirty-three years later, is PBS still worth it? [...] Forsyte should delight the Masterpiece faithful, but that shouldn't be PBS's only ambition. Ironically, PBS is hailing this as the production that brings it into the 21 st century. More like the early 20 th. ${ }^{\text {lviii }}$

The press has frequently criticised a perceived 'comfy' risk-avoidance that evades challenging, politically sensitive drama, which fits in with disappointed hopes and expectations regarding the political potential of PBS, and disavows the presence of such challenging, politically sensitive drama. The press has also been critical of the middleaged, middle-class Masterpiece Theatre audience, for its perceived snobbish elitism and cultural exclusivism. This resists long-standing beliefs in British cultural superiority 
within the United States, including the long-standing view of the superiority of British television, in which PBS and Masterpiece Theatre have been implicated, and somewhat challenged by the acclaim and success of US television drama in the 1990s and 2000s; beliefs that have always served social stratification within the United States. Furthermore, Laurie Ouellette has made the point that one of the fundamental issues with public television is that it was 'conceptualized for the people, not by people, because the terms of its existence presumed their failure as citizens and cultural arbiters. ${ }^{\text {lix }}$ Such a view of the audience as needing to be perpetually transformed by having programming brought to them, and in the case of Masterpiece Theatre, quite literally brought to them from afar, has not sat uncontroversially within US press and self-discourses.

Related to this, a further point of contention has concerned the issue of domestic productions: the regular Masterpiece Theatre audience expressed itself critical of the American Collection, Masterpiece Theatre's move in 2001 to draw in new viewers by funding US productions:

[Masterpiece Theatre] has been uniformly excellent and the best thing on television. The exception was the American production Cora Unashamed [(2000-01)], which had [...] typical American television production values. Please, keep it British - they do these things so much better. ${ }^{1 x}$

The press, on the other hand, welcomed these US productions on Masterpiece Theatre:

[This] is a praiseworthy maiden voyage for PBS' new showcase of dramas based on American classics. If future installments $[\ldots]$ are as strong as 'Cora,' those Masterpiece Theatre Brits will finally be getting some healthy competition from their American cousins. ${ }^{1 \times i}$

That PBS and Masterpiece Theatre do not show more US drama, and more challenging American drama, has been a continual criticism. This has likely been amplified by the international acclaim of both US cable and network drama series in the 1990s and 2000s. It seems somewhat ironic given the increasingly closed off quality of the consolidated US 
market, whose structures of vertical integration, practices of deficit financing and demands for production capability, serve to obstruct market access and entry for foreign competitors. To some extent hinting at a blind spot of such a kind, the US press criticism nevertheless suggests a concern with long-standing discourses in which British drama is equated with quality.

Maybe the Masterpiece Theatre shorthand has not only been convenient and habitual, but continually overlooking the actual diversity of the programming furthermore has suited the press's critical project, as it has helped to keep the anthology series an identifiable target in the US press's engagement with long-standing cultural discourses

and concerns over public broadcasting, as well as domestic production. ${ }^{\text {1xii }}$ So both audiences and press have had (albeit different) reasons for not moving away from the perceived brand identity, which looks likely to persist.

Given the tensions that mark Masterpiece Theatre, especially the oscillation between heterogeneity and homogeneity, it is not surprising that it underwent a substantial change in 2008, whereby the series was split into three sub-strands. This division means that the diversity of the programming is now more easily manageable, and that tensions within broadcasting and promotional strategies can be separated out more. The contemporary, the heritage and the crime/detective dramas have their own defined and visible seasonal slot. Perhaps this sub-division was inevitable, as the diversity of Masterpiece's programming would always place (too) much tension on the one label of Masterpiece Theatre. Of course, while this helps to deliver the preferred kinds of programming to the Masterpiece viewers, it means that these viewers are less likely to come across that sense of diversity, less likely to have their taste preferences extended.

\section{Conclusion: Trans-Atlantic Assumptions, Perceptions and Conceptualisations}

I would like to conclude my discussion by thinking about some of the US assumptions and perceptions of British television as they have been influenced by the long-standing presence of Masterpiece Theatre. ${ }^{\text {lxiii }}$ Given Masterpiece Theatre's presence and emphasis on the quality of its programming, there has been, as Alistair Cooke put it, an assumption within the United States 'that any good drama that was made in Britain was on Masterpiece Theatre ${ }^{\text {, lxiv }}$ There has been a substantial amount of misremembering and 
misattribution, to the extent that Masterpiece is compelled to point out on its website that the first The Forsyte Saga, The Pallisers and Brideshead Revisited were not actually shown on Masterpiece Theatre. ${ }^{1 \mathrm{xv}}$

Of course, not all good British drama has made it across the Atlantic: for example, serialised drama, useful for building audiences, has been preferred to single-plays and one-off dramas, which in many British discourses would be considered among the best of British drama. As with US imports on British television, what American audiences get to experience of British drama has tended to be a small, quite unrepresentative selection, which has distorted US notions of British television drama, let alone British quality drama, as O'Connor pointed out in the New York Times as early as 1974:

Since British imports go through such a rigorous screening and purchasing process, survival for American consumption tends to be reserved for the better specimens. As a result, many Americans have the impression that British TV offers an endless progression of well-acted and beautifully mounted dramas, subtly wrapped in cocoons of elevated intentions. That is, of course, nonsense. [...] [E]ven their dramas, undoubtedly a British speciality, are riddled with duds. $^{\text {lxvi }}$

Thinking about British imports on US television raises the issue of British perceptions of British drama at a historiographical and conceptual level. Scholars in Britain working on domestic British drama need to be mindful of the different dimensions of British drama's manifold identities; that the British drama watched in Britain is not the same as the British drama as it appears in other countries (including, but of course not restricted to, the United States), marked as it is by particular broadcasting processes. Not simply being exported, but also increasingly produced to be exported and exportable in a global marketplace, British drama has been part of trans-national broadcasting processes, and they have been part of and shaped British drama.

For example, were it not for WGBH and Masterpiece Theatre, not only would there have been no kiss between Anne Elliot and Frederick Wentworth in the final scene of Persuasion (1996-97), ${ }^{\text {lxvii }}$ but high-end British drama such as Persuasion or Cranford, would not exist, at least not in the volume it continues to. Interesting power-relationships and inter-dependencies between the British and US television markets persist, where 
boundaries are revealed as porous, tensions of national identities bound up in public broadcasting systems emerge, and self-sufficient definitions cannot suffice. Conventional historical understanding is unsettled, both in the sense that historiographical research of this kind is presented with the challenge of having to negotiate at times contradictory information conditioned by the (national) context of its sources, and in the sense that some of this information sits awkwardly within a range of discourses. For example, given Mobil Oil's influence with regard to WGBH's programming decisions and therefore ultimately British television production, Jarvik's suggestion that Mobil Oil's vice president for public relations Herb Schmertz became known among British television producers as 'the most powerful man in English television', lxiii would most likely cause discomfort to some British discourses concerned with broadcasting, and reinforces Michele Hilmes's call for 'a further breaking open of the national box within which histories of broadcasting are so often written' lxix As the textual instability underlying Masterpiece Theatre suggests, texts move from one set or zone of discourses of tensions to another, and the analysis of this movement and these tensions can usefully defamiliarise what has so often seemed familiar and self-evident, highlighting historical contingency in all its fascinating messiness.

\section{Acknowledgments}

I thank the staff at the Library of American Broadcasting, the National Public Broadcasting Archives and the Library of Congress, as well as Dr. Elke Weissmann for kind help with archive materials. I am grateful to Professor Everett Frost (Executive Producer and Project Director, Radio Drama, WGBH, 1982-1985) for his generous comments on drafts of this essay. This essay is one of the outcomes of the AHRC-funded research project 'British Television Drama and Acquired US Programmes, 1970-2000' at the University of Reading.

\footnotetext{
${ }^{\text {i }}$ See Simone Knox ,'Five's Finest: The Import of CSI to British television,' in Mike Allen, ed, Reading CSI: Crime TV Under the Microscope, I.B. Tauris, 2007, pp. 183-197.

${ }^{\text {ii }}$ See Laurence Jarvik, PBS: Behind the Screen, Forum, 1997, and Masterpiece Theatre and the Politics of Quality, The Scarecrow Press, 1999; Jeffrey S. Miller, Something Completely Different: British Television and American Culture, University of Minnesota Press, 2000; Jeanette Steemers, Selling Television: British Television in the Global Marketplace, BFI, 2004.
} 
${ }^{\text {iii }}$ Steemers, Selling Television, p. 144. As is often pointed out during conference discussions, The Avengers (ABC, 1966-1969) is still the only British drama series to have been used by a (commercial, over-the-air) US network during ratings sweeps.

${ }^{\text {iv }}$ Ibid., xiv.

" Jeanette Steemers, "No Longer "The Best in the World": The Challenge of Exporting British Television Drama,' Media International Australia. 115, 2005, 40.

${ }^{\mathrm{vi}}$ For a discussion of the similarities between PBS and the BBC, see Miller, Something Completely Different, pp. 85-89. One crucial difference is that PBS receives a federal subsidy but does not enjoy the economic stability and muscle provided the BBC by the licence fee.

vii Please note that my date references refer to the specific season in which programmes were first broadcast on Masterpiece Theatre. For the sake of readability, I exclude repeats of programmes, and focus on the first series of longer-running shows. The full complexity of Masterpiece Theatre's programming history can be gleaned here: http://www.pbs.org/wgbh/masterpiece/archive/programs.html.

viii Miller, Something Completely Different, p. 91.

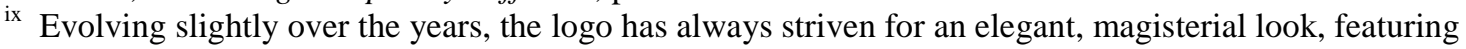
curlicues above and below the words 'Masterpiece Theatre.'

${ }^{x}$ See Charlotte Brunsdon, 'Problems with Quality,' Screen, 31, 1, 1990, 67-90. Brunsdon has identified the following components for the Brideshead/Jewel paradigm: the literary source, the best of British acting, money and heritage export. Jewel in the Crown was shown on Masterpiece Theatre during the 1984-85 season; Brideshead Revisited was broadcast on PBS' Great Performances series in 1982.

${ }^{x i}$ Miller, Something Completely Different, p. xv. It is worth recalling Brunsdon's point that heritage television is not so much a question of genre, but 'a category delineated partly through its representational domain, a certain image of England, partly through its dominant structure of feeling, an elegiac nostalgia, and partly through its production values and export destiny, which offer the (tasteful) pleasures of money on the screen.' Charlotte Brunsdon, 'Structure of Anxiety: Recent British Television Crime Fiction,' in Edward Buscombe, ed, British Television: A Reader, Oxford University Press, 2000, pp. 202-3.

${ }^{x i i}$ Miller, Something Completely Different, p. 85.

xiii Ibid., p. xv.

${ }^{\text {xiv }}$ Erik Barnouw, The Sponsor: Notes on Modern Potentates, Transaction Publishers, 2004, p. 150.

Barnouw's turn of phrase has come to be associated with Masterpiece Theatre, partly because a significant number of the programmes cited in his influential discussion of public television were Masterpiece Theatre programmes. However, Barnouw was not criticising Masterpiece Theatre as such, but instead concerned with the unfulfilled potential of public television.

${ }^{\mathrm{xv}}$ James Poniewozik, 'Anarchy from the U.K.,' Time Magazine, 5 June 2000, 65.

${ }^{x v i}$ Then-Channel 4's programme director Jeremy Isaacs commented on Masterpiece Theatre as follows: '[V]irtually nothing from British TV is shown on American television [...]. Most of what is shown is the worst of what we do. Masterpiece Theatre concentrates on simple, safe costume dramas.' Cited in Richard Zoglin, “'Channel Snore” to the Fore,' Time Magazine, 1 September 1986, 64.

${ }^{x v i i}$ Steemers, Selling Television, p. 118.

xviii Cooke in Laurence Jarvik, 'Transcript of interview with Alistair Cooke,' The Papers of Laurence A. Jarvik. National Public Broadcasting Archives, 1990.

xix Ibid.

${ }^{x x}$ Paul Lee, then-BBC America's chief operating officer, cited in Poniewozik, 'Anarchy from the U.K.'

${ }^{x \times i}$ Steemers, Selling Television, p. 143. Of course, while Masterpiece Theatre's brand reputation has fitted in well with the BBC's public service obligations - the BBC has promoted itself as 'bringing the best of British culture [...] to audiences all over the world' (BBC, Initial Submission to the Government's Communications Review, BBC, 2000, p. 30) - selling programming to Masterpiece Theatre has also complicated issues of branding.

xxii The 2008 Jane Austen season on Masterpiece, billed on the website as offering 'the complete Jane Austen', included not only the mid-2000s ITV1 productions, but also the 1995 BBC Pride and Prejudice, which was co-produced by and successfully shown on A\&E. An increasing fluidity regarding branding is at play in the increasingly fragmented US market, which interestingly complicates my discussion of competition and brand identities. 
xxiii See Laurie Ouellette, Viewers Like You?: How Public TV Failed The People, Columbia University Press, 2002, p. 215.

${ }^{\text {xxiv }}$ Eaton cited in Chauncey Mabe, 'A Television Masterpiece,' TWA Ambassador, January 1991, 37.

${ }^{x x v}$ Joan Sullivan, 'Re: Masterpiece Theatre Broadcast Schedule, Season 1977-1978,' Memo to Henry

Becton. 19 June 1977, National Public Broadcasting Archives. The 'UP/DOWN' refers, of course, to Upstairs, Downstairs.

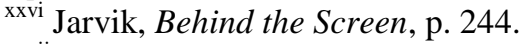

xxvii See ibid., p. 242

xxviii See Jarvik, Behind the Screen, pp. 237-258.

${ }^{\text {xxix }}$ Ibid., 237.

${ }^{\mathrm{xxx}}$ Jarvik's discussion has even sought to resolve this sense of tension: 'The return to the 1950s form of sponsored television anthology drama was perhaps the most significant aesthetic achievement of Masterpiece Theatre. For in so doing, no matter how feminist, working class, or even revolutionary the message of an individual show, the very format in which it would be presented defused any potentially explosive reaction from offended audiences or sponsors [...].' Jarvik, Politics of Quality, p. 210.

${ }^{x x x i}$ Steemers, Selling Television, p. 112

xxxii Indeed, further complexity is introduced to engagement with this shorthand by the fact that, because of synergetic creative networks at WGBH, Masterpiece Theatre has had a positive effect on PBS public affairs series Frontline.

xxxiii See Jarvik, Behind the Screen and Politics of Quality, for further details on the struggle over Upstairs, Downstairs between WGBH, PBS and Mobil Oil.

xxxiv Ibid.

${ }^{x x x v}$ Audience comment from the Masterpiece Theatre online forum, available via http://www.pbs.org/wgbh/masterpiece/forum/read.html, 2001.

${ }^{\mathrm{xxxvi}}$ Masterpiece Theatre online forum, 2002.

xxxvii WGBH statement on the Masterpiece Theatre online forum, 2001.

xxxviii Masterpiece Theatre online forum, 2001.

${ }_{\text {xxxix }}$ The posters are available at http://www.pbs.org/wgbh/masterpiece/archive/poster_gallery.html\#.

${ }^{\mathrm{xl}}$ Miller, Something Completely Different, p. 102.

${ }^{x l i}$ See ibid., p. 178.

xlii Laurie Ouellette makes the fascinating point that, at a time of significant racial unrest, a range of PBS programming, including Masterpiece Theatre and The French Chef (1962-73), affirmed white European cultural heritage in ways that disavowed race as an issue, whilst popular 'minority' programming for black audiences on PBS was being phased out. See Ouellette, Viewers Like You?, 146-163.

xliii Cooke cited in Val E. Limburg, 'Cooke, Alistair (1908-2004)' in Horace Newcomb, ed, Encyclopedia of Television; Volume 1: A-C, Second Edition, Fitzroy Dearborn, 2004, p. 583.

${ }^{\text {xliv }}$ For an insightful discussion of Cooke's career as a focal point of negotiations over 'Americanness' and 'Britishness' within British and American contexts respectively, see Michele Hilmes, 'The 'North Atlantic Triangle': Britain, the USA and Canada in 1950s television,' Media History, 16, 1, 2010, 31-52.

${ }^{x l v}$ Cristina Odone, 'Cooke botoxed the US of its wrinkles,' The Observer, 7 March 2004, p. 47. Jarvik has pointed out that, the abundance of signifiers of British culturedness and quality traditions notwithstanding, Masterpiece Theatre is also visibly linked to US quality television drama traditions, being 'a 1950s-style anthology television drama sponsored by a major corporation.' Jarvik, Politics of Quality, p. x.

xlvi Given that the 'Otherness' of The Murder of Stephen Lawrence was repeatedly highlighted, it is interesting to note that its scheduling on Masterpiece Theatre sought to make a connection to the US viewing context: it was broadcast on Martin Luther King Jr. Day.

xlvii See Brooke Gladstone, On The Media, Interview with Rebecca Eaton. WNYC Radio. 14 May 2004. (Eaton did not specify which Prime Suspect episodes were affected by this.)

xlviii See Sullivan, 'Masterpiece Theatre Broadcast Schedule.'

${ }^{x l i x}$ More often than not, these quality British dramas have been assumed by US audiences and critics to be BBC productions.

${ }^{1}$ See Miller, Something Completely Different, and Jarvik, Politics of Quality, for more details on the sponsorship and its implications.

${ }^{l i}$ Grade in Jarvik, 'Transcript of interview with Michael Grade.' 
lii This is not dissimilar to my argument concerning the function and significance of US imports for British broadcaster Five; see Knox, 'Five's Finest.'

liii Miller, Something Completely Different, p. 180.

${ }^{\text {liv }}$ Peter Fiddick, 'A British Perspective,' in The Museum of Broadcasting Celebrates Mobil \& Masterpiece Theatre: 15 Years of Excellence, The Museum of Broadcasting, 1986, 32.

${ }^{1 v}$ Some viewers have also constructed themselves in opposition to the medium of television. Such discourses of distinction between regular television and quality television, as well as regular audiences and quality audiences, well known in recent years from debates on $\mathrm{HBO}$, are evidently nothing new.

lvi Masterpiece Theatre online forum, 2004.

lvii Rick Marin, 'Something Old, Something New,' Newsweek, 9 October 1995, 68.

lviii James Poniewozik, 'Still Your Grandfather's PBS,' Time Magazine, 7 October 2002, 64.

lix Ouellette, Viewers Like You?, p. 221. In this excellent monograph, Ouellette (at least implicitly) accepts the conventional, homogenising views of Masterpiece Theatre as 'safely splendid.'

${ }^{\mathrm{Ix}}$ Masterpiece Theatre online forum, 2001.

lxi Ramin Zahed, 'Cora Unashamed,' Variety, 23 October 2000, 21.

${ }^{\text {lxii }}$ At the same time, this brand identity has also been a protective tool for WGBH when responding to criticism from the political right.

Ixiii For a consideration of the influence Masterpiece Theatre has had on US television production, see Miller, Something Completely Different, and Elke Weissmann, 'Travelling Cultures: The Development of the American Mini Serial and its Import to Britain,' Journal of British Cinema and Television, 6, 1, 2009, 41-57.

lxiv Cooke in Jarvik, 'Transcript of interview with Alistair Cooke.'

${ }^{\text {Ixv }}$ Their PBS broadcast dates were 1969-1970, 1977 and 1982 respectively.

lxvi John J. O'Connor, “'Edwardians” Points to B.B.C. Ups and Downs,' New York Times, 19 July 1974, 71.

${ }^{\text {lxvii }}$ See Steemers, Selling Television, p. 115. I am undoubtedly not the only one who is here put in mind of the kiss between Jennifer Ehle and Colin Firth's Elizabeth Bennet and Mr Darcy at the end of Pride and Prejudice.

lxviii Jarvik, Politics of Quality, p. 118.

${ }^{\text {Ixix }}$ Hilmes, 'The 'North Atlantic Triangle',' 47. 